\title{
Conditions for soil erosion by water in the upper Parsęta catchment
}

\author{
Józef Szpikowski ${ }^{1 *}$, Mikołaj Majewski ${ }^{1}$, Wojciech Madaj² \\ 'Instiute of Geoecology and Geoinformation, Adam Mickiewicz University in Poznań, Poland, "szpiko@amu.edu.pl \\ 2Środa Wielkopolska, Poland
}

\begin{abstract}
The paper presents potential soil erosion risk of the upper Parsęta catchment (Drawskie Lake District, NW Poland). The model considers following conditions affecting the size of soil erosion: slope gradient, LS factor, lithology, land use and land cover. Thematic maps have been reclassified into a 4-degree division. Potential soil erosion risk map was prepared on the basis of thematic maps. Areas with small and moderate susceptibility to soil erosion occupy $71.5 \%$ of the catchment area. The 4 th class of erosiveness is represented by the river valley slopes, steep slopes of kame and moraine hills, covering $28.5 \%$ of the upper Parsęta catchment.
\end{abstract}

Keywords: soil erosion, soil erosion risk map, the upper Parsęta catchment, modelling, GIS

\section{Introduction}

Soil erosion by water belongs to contemporary morphogenetic processes that greatly participate in shaping the relief of the terrain (Gerlach 1966, Gil 1976). In particular, this applies to areas used for agriculture in the temperate climate zone (Kostrzewski 2001, Smolska 2002, Szpikowski 2003). The problem of soil erosion by water is studied as a geomorphological factor that influences the relief (denudation) and as a process that degrades the soil cover. The need to protect soils has influenced not only the development of knowledge of soil erosion mechanisms, but it has also led to the development of numerous activities limiting its size - especially on the cultivated slopes (Kosturkiewicz et al. 1994, Koćmit 1998).

The greatest amount of reliable data on the size and conditions of soil erosion comes from stationary, long-term research on specially prepared testing plots. Field and laboratory experiment methods are also used. These are costly and labour-intensive methods. They cannot cover a larger area of research therefore the obtained results can only be considered representative of a specific region. For numerous and very variable conditions of soil erosion by water in the geographical space, approximation of results from point studies can lead to large errors.
Numerous studies have been undertaken in which the distribution and intensity of the soil erosion risk in space is predicted based on specific features of the geographical environment. For this purpose, soil erosion risk maps are prepared. They can be divided into qualitative and quantitative studies. Qualitative ones present soil erosion risk classes (Józefaciuk et al. 1985, Józefaciuk, Józefaciuk 1992, 1994, Mularz 1995, Le Bissonnais et al. 2002, Š́ri et al. 2002, Vrieling et al. 2002, Drzewiecki et al. 2014). Quantitative studies forecast soil erosion values from a given area (Vold et al. 1985, Erhard et al. 2003, Kirkby et al. 2004, Lu et al. 2004, Mularz, Drzewiecki 2007, Milevski 2008, Bosco et al. 2009, Martín-Fernándes, Martínez-Núňez 2011, Wężyk et al. 2012, Farhan et al. 2013, Perović et al. 2013, Prasuhn et al. 2013), based on erosion models such as: USLE - Universal Soil Loss Equation (Wischmeier, Smith 1978), WEPP - Water Erosion Prediction Model (Laflen et al. 1991), RUSLE - Revised Universal Soil Loss Equation (Renard et al. 1997), EUROSEM - European Soil Erosion Model (Morgan et al. 1998), PESERA - Pan-European Soil Erosion Risk Assessment (Kirkby et al. 2004), G2 (Panagos et al. 2015). The use of empirical models to determine the risk of soil erosion requires a large amount of detailed data which is often unavailable for larger areas or data estimated based on other premises only. Ero- 
sion models are usually prepared for specific regions, which make it difficult to apply them to other areas with different geographic features (Favis-Mortlock et al. 1996, Vrieling et al. 2002). Due to these difficulties, the use of valorisation of particular factors affecting erosion and the preparation of a qualitative map may have a wider application in the risk assessment of soil erosion. To make such maps, there are often used conditions of erosion processes from empirical models.

Maps presenting soil erosion present it as potential erosion and actual erosion. Potential soil erosion depends on natural factors: climate, relief, soil type. A more dynamic indicator is the actual soil erosion that apart from natural factors also includes economic elements: land use and land cover, applied agrotechnics and anti-erosion activities (Koreleski 1992, Józefaciuk, Józefaciuk 1999, Šúri et al. 2002, Vrieling et al. 2002, Erhard et al. 2003).

In studies on spatial diversity of actual soil erosion, the classification method of the main erosive factors is commonly used: precipitation, soil susceptibility to erosion, slope gradient (Józefaciuk, Józefaciuk 1992, Tricart, Kiewiet de Jonge 1992, Šúri et al. 2002, Drzewiecki et al. 2014), land use and land cover, as well as agrotechnical procedures (Le Bissonnais et al. 2002, Wawer, Nowocień 2006, 2007). Attention is drawn to the great importance of indicators related to relief: slope, LS (sediment transport capacity index), planar and vertical curvature, SPI (Stream Power Index) and TWI (topographic wetness index) (Milevski 2008).

For the upper Parsęta catchment located in the Drawskie Lake District, no maps of actual soil erosion have been made so far. Existing studies for this area come from maps covering the whole of Poland (Reniger 1950, Józefaciuk, Józefaciuk 1992, 1994, Wawer, Nowocień 2006, 2007, Wawer et al. 2008), the region of Przymorze (Józefaciuk et al. 1999) or administrative units in the scale of the voivodeship (Józefaciuk et al. 2001a, 2001b).

The main objectives of the research undertaken as part of this study are:

- indication of the conditions of soil erosion such as: morphology, lithology, land cover and land use,

- development of a homogeneous risk classification with potential soil erosion based on the indicated conditions,

- implementation of a numerical map of potential soil erosion in the upper Parsęta catchment using bonitation method.

\section{Study area}

The upper Parsęta catchment is located in north-western Poland, within the Central Pomerania region, in

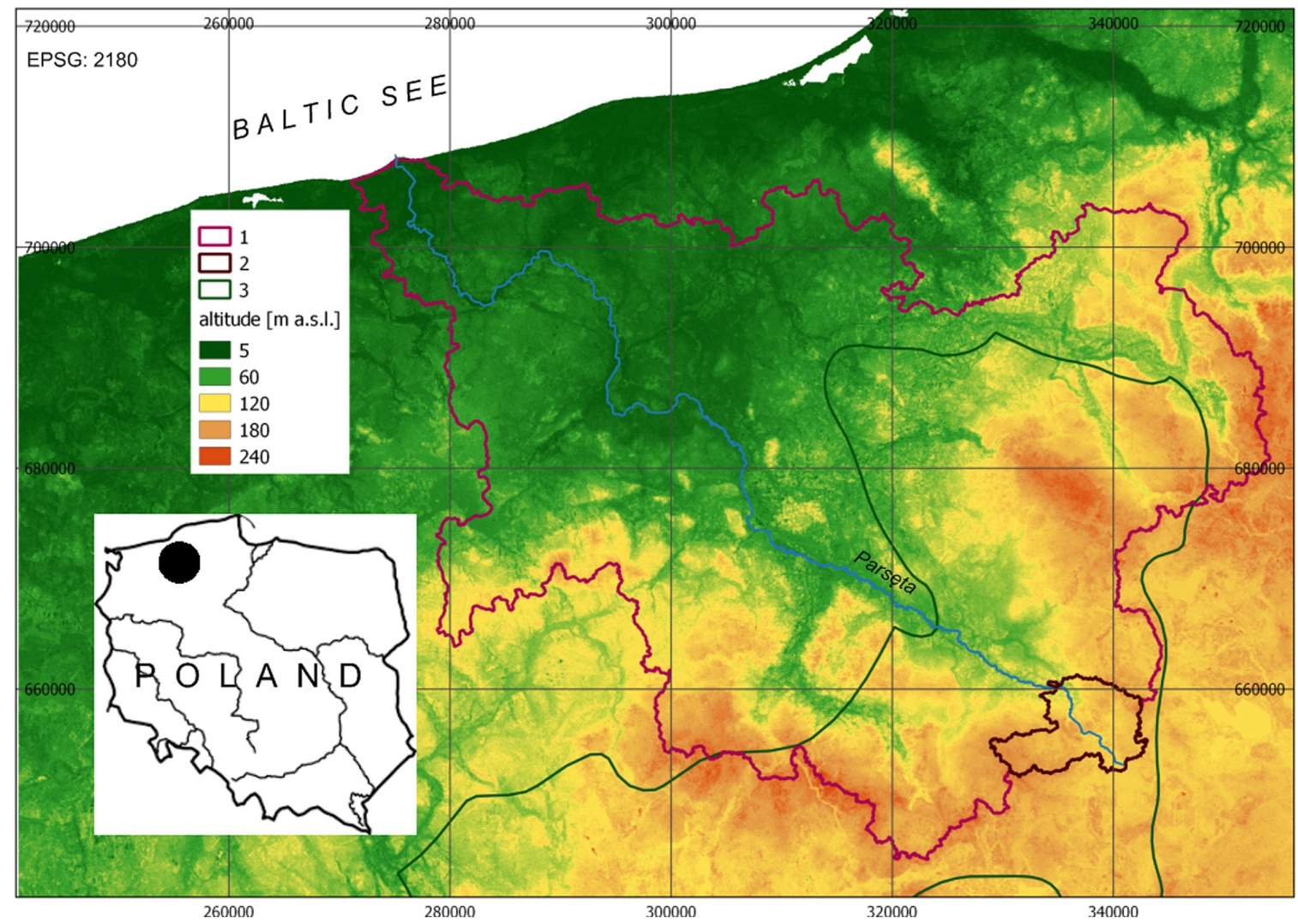

Fig. 1. Localisation of research area

1 - the Parsęta catchment, 2 - the upper Parsęta catchment, 3 - Drawskie Lake District. DEM from ASTER-GDEM 
the mesoregion of the Drawskie Lake District (Fig. 1). It represents the young glacial, lowland geoecosystem of lowland Poland. The current relief and lithology were shaped during deglaciation of the Pomeranian phase of the Vistula glaciation (Karczewski 1989) and in the Holocene (Kostrzewski et al. 2008). Characteristic elements of the Pleistocene landforms are undulating plains of the ground moraine, end moraine hills, crevasse forms, outwash plains, melting depressions of variable sizes and ice-dammed lakes. Holocene elements of the landforms include: river valleys, detrital fans, dry valleys, gullies and peat plains. Human activity is marked in the relief of terrain through various anthropogenic forms such as embankments and excavations, mining areas, field balks and agricultural terraces (Szpikowski 2012). The upper Parsęta catchment covers an area of 74 $\mathrm{km}^{2}$, and the length of its watershed is $58.3 \mathrm{~km}$. The average density of the river network is $2.24 \mathrm{~km} \mathrm{~km}^{-2}$, and the average catchment gradient is $8.4 \%$. The highest elevation is Polska Góra, with an altitude of $202.8 \mathrm{~m}$ a.s.l. The main watercourse draining the basin is the Parsecta River that is sourced in a mineral-organic accumulation marginal lake at an altitude of approximately $137.5 \mathrm{~m}$ a.s.l., near the village of Parsęcko. The basin area of the upper course of Parsęta ends in Storkowo, near a former mill, and now the Geoecological Station of the Adam Mickiewicz University in Poznań. The cross-section closing the upper river course is located at an altitude of 83.4 $\mathrm{m}$ a.s.l. therefore the denivelation of the research area is almost $120 \mathrm{~m}$. The length of the Parsęta River to the section closing the upper Parsęta catchment is $13.3 \mathrm{~km}$ long.

\section{Research methods}

The main source of data required for the preparation of a map of potential soil erosion in the upper Parsęta catchment was cartographic materials. The digital elevation model (DEM) for the basin was prepared on the basis of vectorised contour lines on the 1:10 000 scale topographical maps in the PUW 1965 system (sheets: 333.134 Przeradź, 333.143 Nowe Gonne, 333.311 Barwice, 333.312 Radomyśl, 333.313 Ostropole, 333.314 Radacz, 333.321 Dalęcino, 333.323 Szczecinek-Zachód) (Head Office of Land Surveying and Cartography in Warsaw). Data on lithology of the research area was obtained from two sheets (159 Barwice and 160 Szczecinek) of the Detailed Geological Map of Poland in the scale of 1:50 000 (PIG 2004). The information on spatial distribution of land use types and land cover was obtained from Corine Land Cover 2012 vector data (European Environmental Agency in Copenhagen).
The map design also uses other vector data of the basin such as: watershed, watercourses and larger water reservoirs (designated on the basis of maps on a scale of 1:10 000 and verified in the field). All spatial data was transposed into the Polish CS92 coordinate system (EPSG 2180). In this system, thematic maps of conditions and final maps of potential soil erosion were also prepared.

The file with vectorised contour lines in *.dat format has been processed into the DEM in the Surfer 10.05 software. The estimation using the ordinary kriging method was used for this purpose (Urbański 2008). The mesh size of the model was assumed to be $5 \times 5 \mathrm{~m}$. Using the DEM in the SAGA GIS software, a slope map was made. The DEM and the slope map were used to create a secondary topographic attribute, which is the LS transportability index. It is based on the slope gradient and the catchment area, i.e. the surface area feeding a given cell divided by the cell side (Urbański 2008). The LS factor was calculated using the SAGA GIS software. In the pre-processing process, depressions were filled in the DEM, and then the outflow directions from the depressions were determined (module Sink Drainage Route Detection in SAGA GUI 2.1.2). This allowed creating the right local basin area. The Digital Elevation Model Network (DEMON) method was used to determine the direction of downflow from a single cell. This method determines the flow path through the highest probability selection algorithm (Costa-Cabral, Burges 1994). The final stage was to connect the appropriate local basin area with a map of slopes and determine the LS factor.

Individual thematic maps of soil erosion were made for the following conditions: slope gradient, LS factor, lithology, land use and land cover. Based on literature data for each thematic map, 4 classes of erosion risk were distinguished: from class 1 - weak erosion, to class 4 - strong erosion. In the case of the LS factor map, for which there is currently no classification that would concern its impact on soil erosion, the division was made according to Jenks' natural breaks. It is an algorithm aiming at the smallest differentiation of observations within intervals, while maximizing the distance between them (Jenks 1967). Vector maps (lithology, land use and land cover) have been transformed into a raster map. In the final stage, all thematic maps were merged into a final map of potential soil erosion. For this purpose, a raster calculator was used and classified maps of slopes, LS factor, lithology, land use and land cover were added to each other. The result map formed was again classified according to four-class compartments. All classified thematic maps were made in the SAGA GIS software. Previously, a table containing the risk class was assigned to each layer in the database. 


\section{Conditions for soil erosion by water in the upper Parsęta catchment - thematic maps}

\section{Hypsometry and slopes}

The DEM analysis indicates that the smallest absolute altitudes within the basin are located along the Parsęta Valley and do not exceed $140 \mathrm{~m}$ a.s.l. (Fig. 2). The river flows through the central basin area from the south-east towards the north-west, and its valley is clearly marked in the relief. Low absolute values characterize the Kłuda valley, which flows almost parallel to Parsęta, and the lower section of Skalneński Potok in the central part of the basin, east of Parsęta. Kettle holes areas clearly appear in the relief, including two largest peat bogs: Chwalimskie Bagno (Chwalimskie Swamp) and the spring area of Parsęta River. The highest located parts of the research area are the upper part of the Żegnica basin and the north-eastern border of the upper Parsęta catchment together with the Polska Góra moraine hill.

Based on the DEM, slopes in the upper Parsęta catchment were determined (Fig. 3). They range from 0 up to $20^{\circ}$. Slopes above $10^{\circ}$ occur in the whole basin, mainly along the edges of river valleys (Parsęta, Kłuda) and the kettle holes and on the slopes of larg-
Table 1. Classes of susceptibility to erosion by slopes in the upper Parsęta catchment

\begin{tabular}{lcccc}
\hline Slope inclination $\left[^{\circ}\right]$ & $0-2$ & $2-5$ & $5-10$ & $>10$ \\
\hline Class of susceptibility to erosion & 1 & 2 & 3 & 4 \\
\hline
\end{tabular}

er kame hills (in the middle part of the upper Parsęta catchment and surrounded by the Polska Góra).

In terms of susceptibility to soil erosion, the Józefaciuk, Józefaciuk (1999) determine 5 classes of slopes: $0-3^{\circ}-$ very low susceptibility, $3-6^{\circ}-$ low susceptibility, $6-10^{\circ}$ - average susceptibility, $10-15^{\circ}$ - high susceptibility, $>15^{\circ}$ - very high susceptibility. Taking into account the lowland location of the upper Parsęta catchment, and hence the smaller denivelations and slope gradient, a four-level division into erosion susceptibility classes according to slopes was introduced (Table 1).

The image obtained after reclassification of the slope map (Fig. 4) indicates that slopes are most favourable for soil erosion (class 4) occur rarely on the edges of river valleys and deeper kettles and on the slopes of the highest kames.

\section{LS factor}

The calculated values of the LS factor for the upper Parsęta catchment are in the range from 0 to 8 (Fig. 5). Similarly to the slope map, the highest values of the

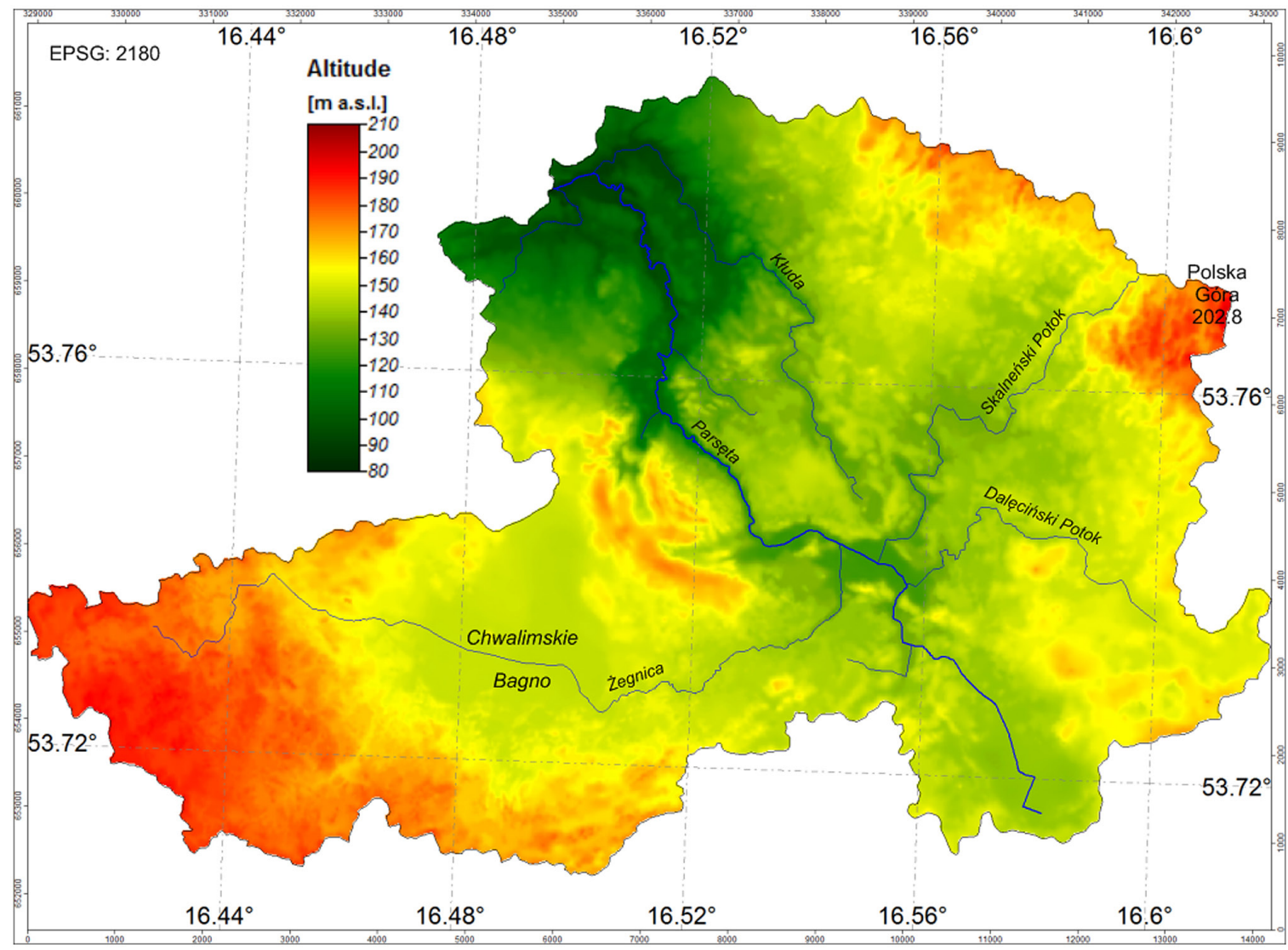

Fig. 2. DEM of the upper Parsęta catchment 


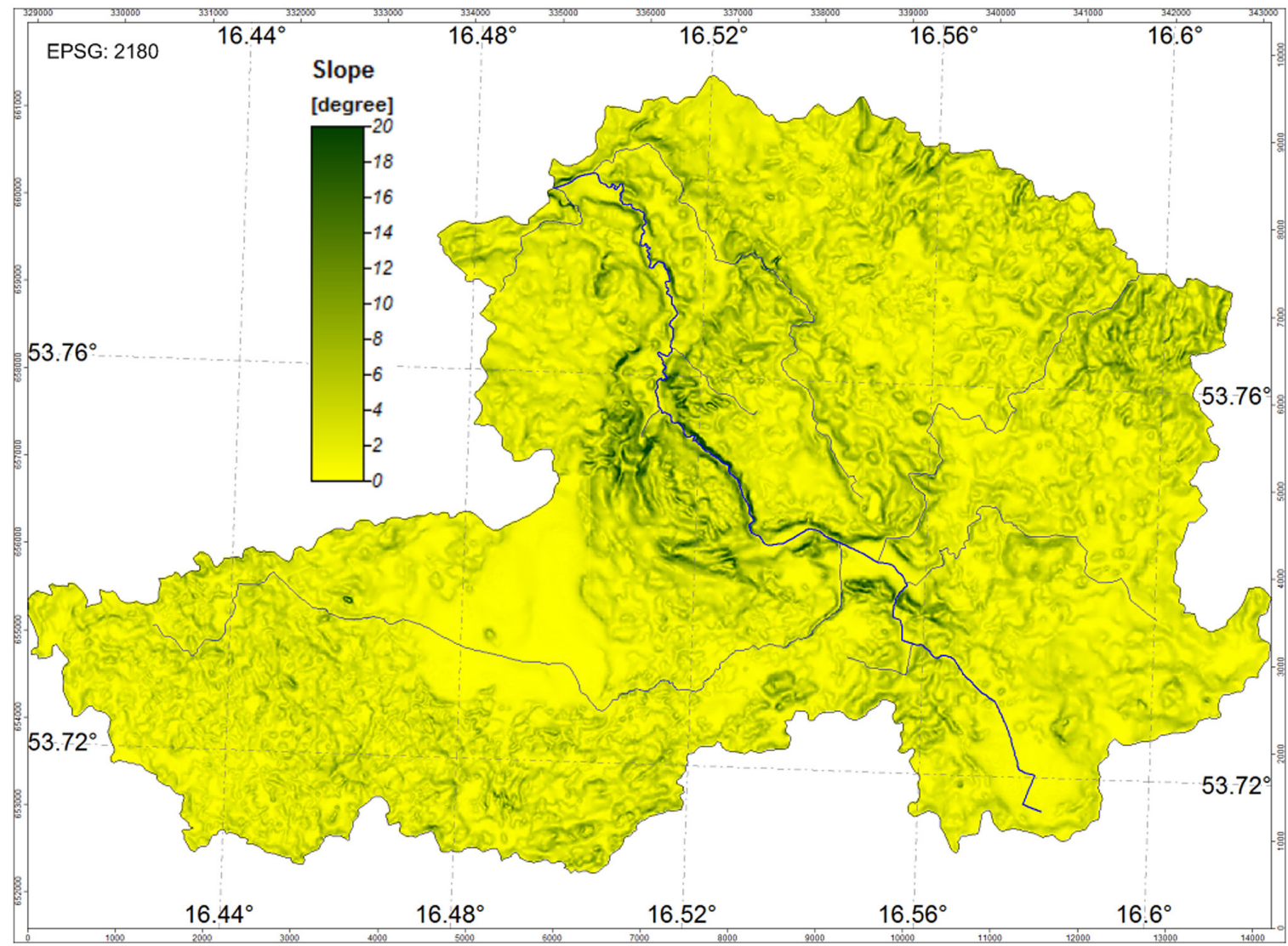

Fig. 3. Slope inclination in the upper Parsęta catchment

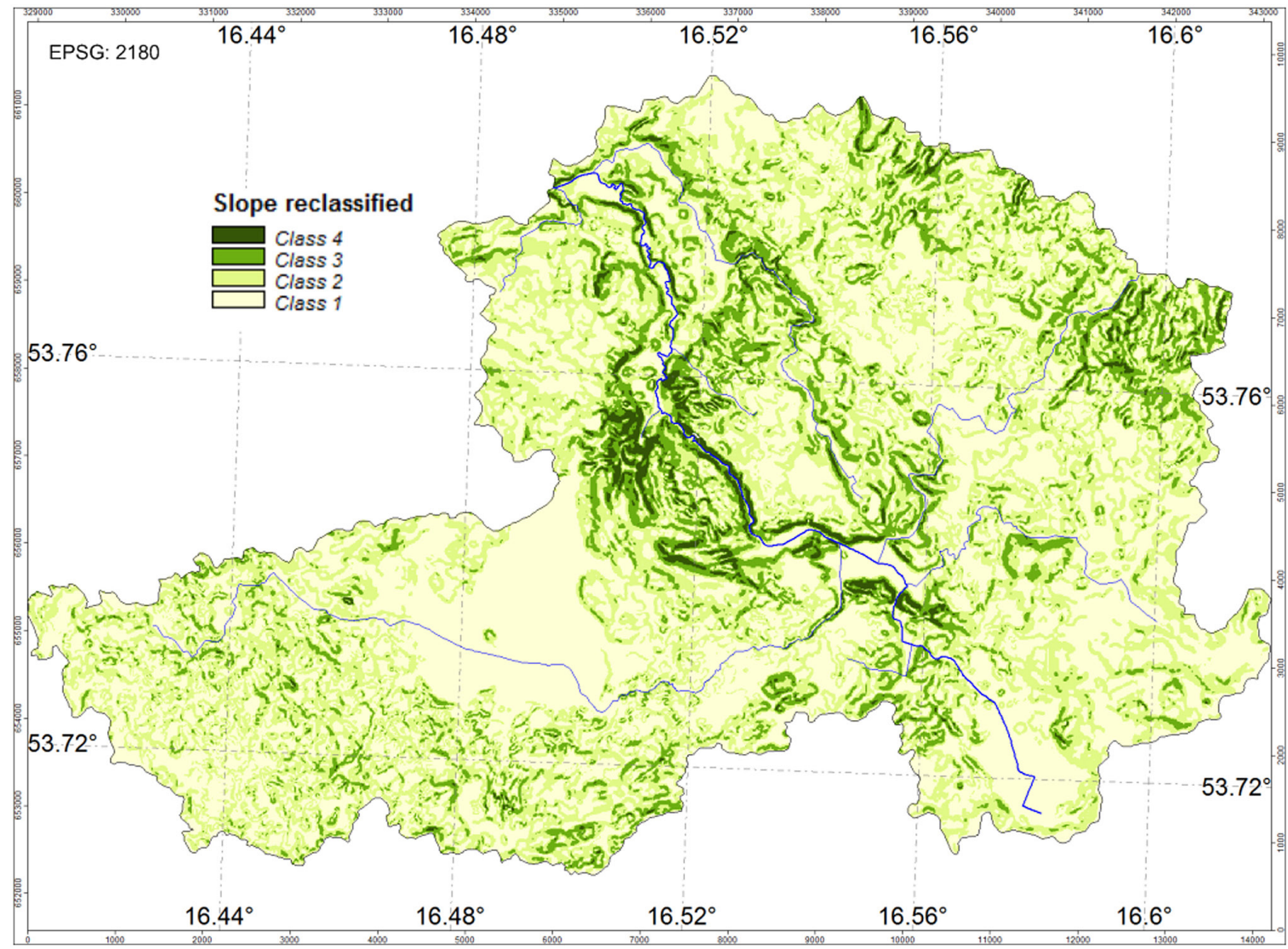

Fig. 4. Reclassified slope inclination in the upper Parsęta catchment 


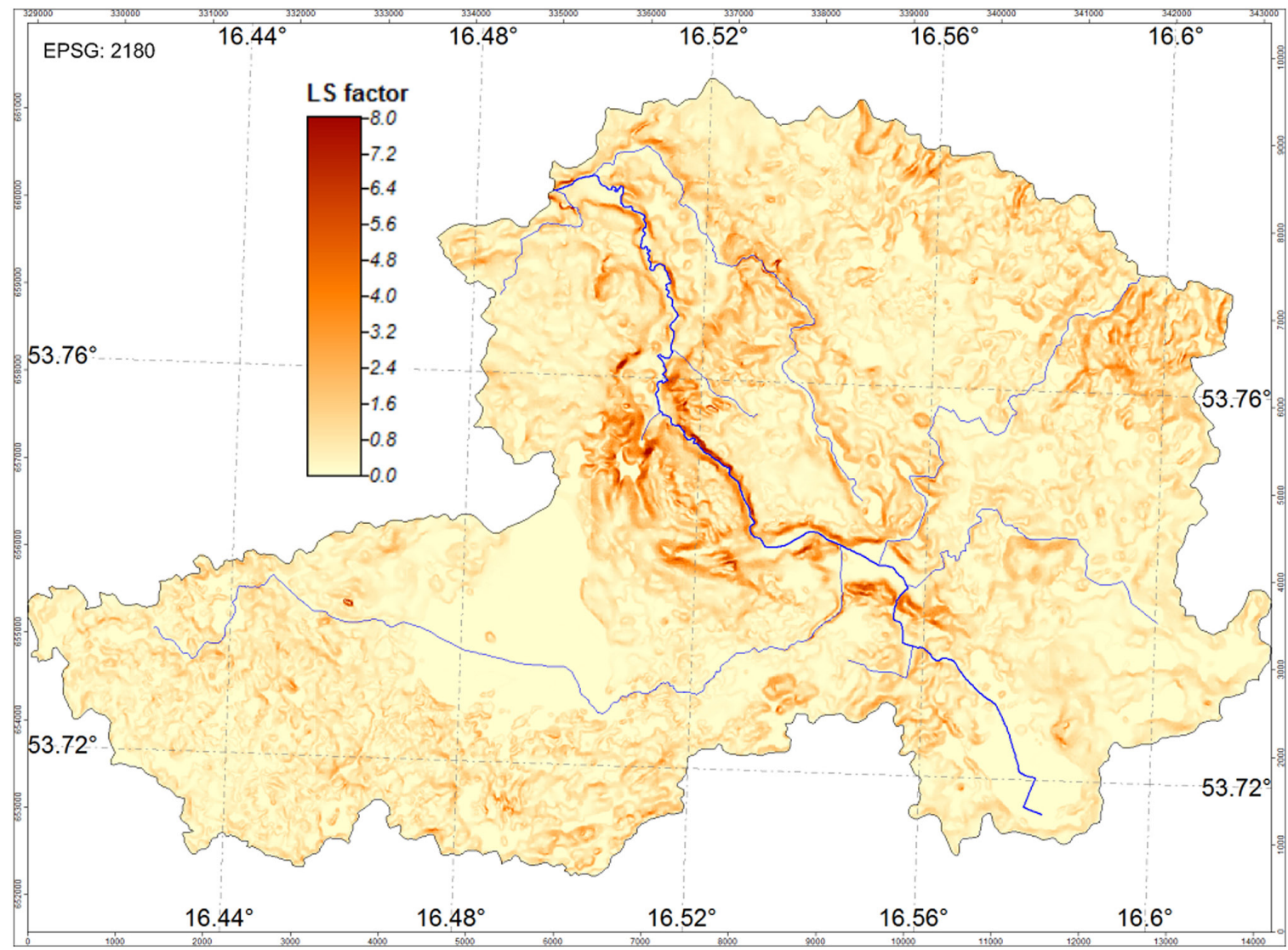

Fig. 5. LS factor in the upper Parsęta catchment

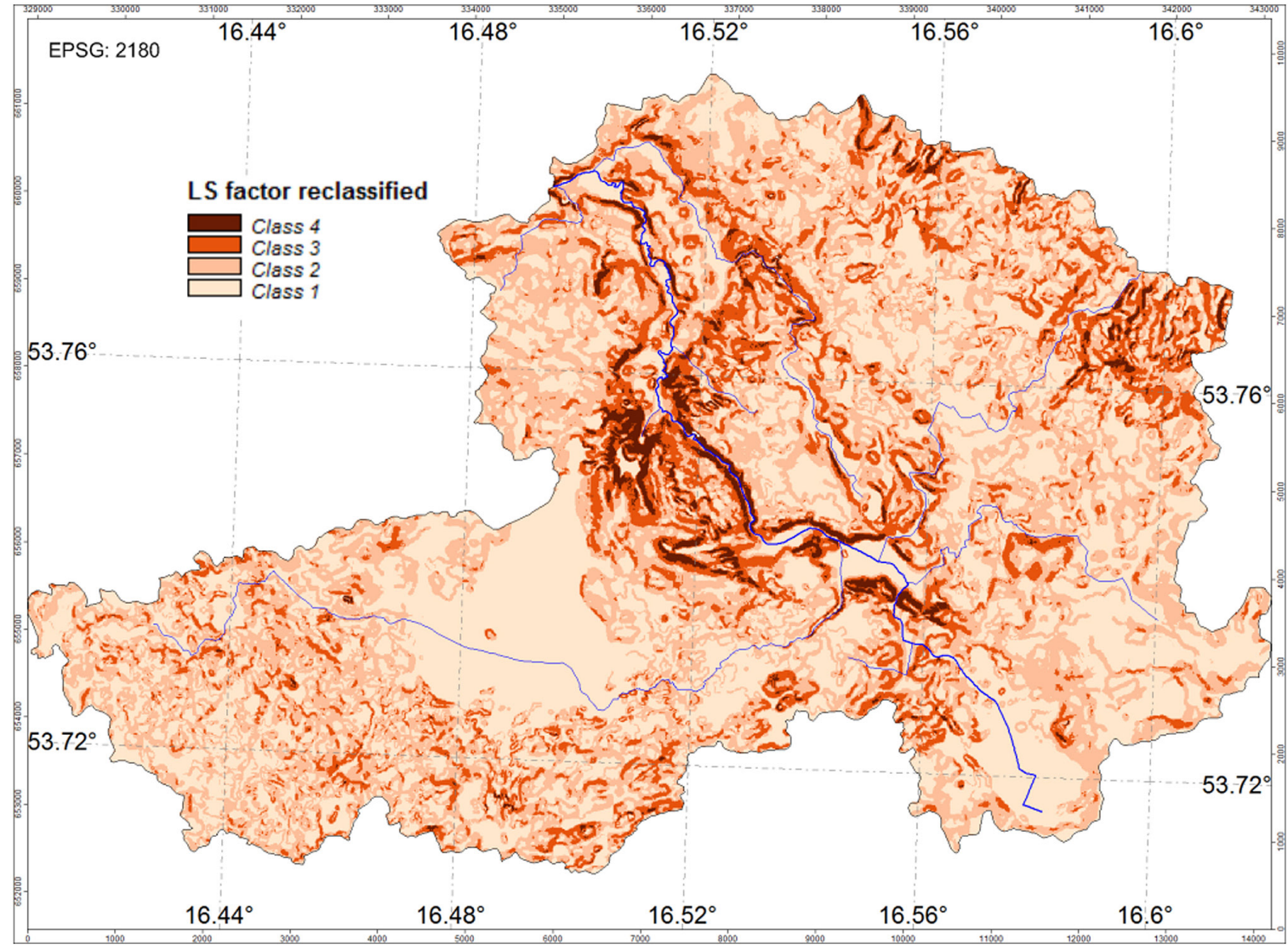

Fig. 6. Reclassified LS factor in the upper Parsęta catchment 
Table 2. Classes of susceptibility to erosion by LS factor in the upper Parsęta catchment

\begin{tabular}{lcccc}
\hline LS factor & $0-0.3$ & $0.3-1.1$ & $1.1-2.7$ & $>2.7$ \\
\hline $\begin{array}{l}\text { Class of susceptibility } \\
\text { to erosion }\end{array}$ & 1 & 2 & 3 & 4 \\
\hline
\end{tabular}

LS factor occur on the edges of river valleys and on the slopes of the highest kame hills. The relief of the upper Parsęta catchment, where short slopes predominate, usually a few to several dozen meters long - makes LS factor values not that high. Classes of susceptibility to erosion according to the LS factor, determined using Jenks' natural breaks, are presented in Table 2 .

The map for the indicated four classes of the LS factor shows a similar spatial differentiation as for the reclassified slope map (Fig. 6). The largest part of the catchment is occupied by areas with class 1 . These are primarily the bottoms of kettle holes, flat parts of moraine uplands and local outwash plains. Class 4 areas are located on the slopes of kame hills and in the edge zones of river valleys.

\section{Lithology and soils}

Another important factor affecting the size of soil erosion by water is lithology and soil type. These factors are interrelated. Physicochemical characteristics of soil greatly affect its susceptibility to erosion. Soil resistance due to firmness is determined by the ratio of fine fraction $(0.1-0.02 \mathrm{~mm})$ to colloidal fraction $(<0.002 \mathrm{~mm})$. The higher it is, the lower the soil resistance (Józefaciuk, Józefaciuk 1996). Smaller parts and parts of low permeability are usually more at risk of erosion (Dobrzański et al. 1953). The exceptions are illitic soils, which, despite low permeability and a high content of small particles, are poorly susceptible to erosion. Sandy soils with high permeability are more at risk. In some models, the properties of soils that change dynamically over time are also more difficult to measure. An example is the resistance of soil to periodic changes in water properties caused by splash or excessive and long-term moisture. Under its influence, the soil composition with favourable water-air ratios can change into a poorly permeable sticky mass with no air. Features that affect resistance include: thickness of humus and transitional layers, depth and properties of underlying rock, and chemical and physical properties of soil that affect the growth of plants (Ziemnicki 1978). The division of soils due to the degree of susceptibility to soil erosion has not been unified in Poland. According to the Józefaciuk, Józefaciuk classification (1996, 1999), five classes of susceptibility to soil erosion can be distinguished, taking into account the properties of the underlying layer:

- the strongest susceptible - loess and silt soils,

- strongly susceptible - sandy soils on loose sands and soils on Cretaceous and Jurassic limestone soils,

- moderately susceptible - soils on poorly-clayey and clayey sands, on gravels and calcareous limestone soils,

- poorly susceptible - soils on sandy loams and sands overlying loam and medium soils formed from sedimentary rocks with a carbonate, non-lime bond,

- very poorly susceptible - illitic soils, soils containing large amounts of skeletal parts and peats.

The soils of the upper Parsęta catchment are characterized by a high degree of diversity due to variable lithology and water conditions. According to the Detailed Geological Map of Poland (2004), the largest catchment area is covered by direct glacier accumulation represented by sands with gravels $(29 \%$ of the catchment area) and gravely sand with admixture of silt $(21 \%)$. What is more, till $(25 \%)$ occupies a large share in Pleistocene formations. The main Holocene formations include peat (10\%), river sands $(3 \%)$ and deluvial sands with gravels (2\%). Less frequent are gyttjas, peaty silts, humic sands and aeolian sands. The distribution of individual lithological formations in the upper Parsęta catchment is characterized by great mosaicism (Fig. 7).

In the absence of homogeneous data on the spatial structure of the upper Parsęta catchment, the classification of the rate of susceptibility to soil erosion was based on the lithology of surface formations according to the Detailed Geological Map of Poland (2004). The proposed sections refer to the Józefaciuk, Józefaciuk classification (1999). The introduced modification results mainly from the lack of soils on loess and silt formations in the upper Parsęta catchment. Due to the deposition of peats, peaty silts and gyttja on flat areas, the degree of susceptibility to erosion for those formations was assumed to be the smallest (class 1). The adopted division is presented in Table 3.

Table 3. Classes of susceptibility to erosion by lithology in the upper Parsęta catchment according to the modified Józefaciuk, Józefaciuk classification (1999)

\begin{tabular}{lc}
\hline \multicolumn{1}{c}{ Lithology } & $\begin{array}{c}\text { Class of suscep- } \\
\text { tibility to erosion }\end{array}$ \\
\hline gyttjas & 1 \\
peaty muds & 1 \\
peats & 1 \\
tills & 2 \\
tills of push moraines & 2 \\
deluvial sands and tills & 3 \\
glacial sands and gravels & 3 \\
glaciofluvial sands with gravels & 3 \\
glacial gravely and dusty sands & 3 \\
sands, gravels and tills of kames & 3 \\
sands, gravels and tills of end moraines & 3 \\
aeolian sands & 4 \\
melt-out dusty sands & 4 \\
fluvial sands of flood plain terraces & 4 \\
humic sands & 4 \\
\hline
\end{tabular}




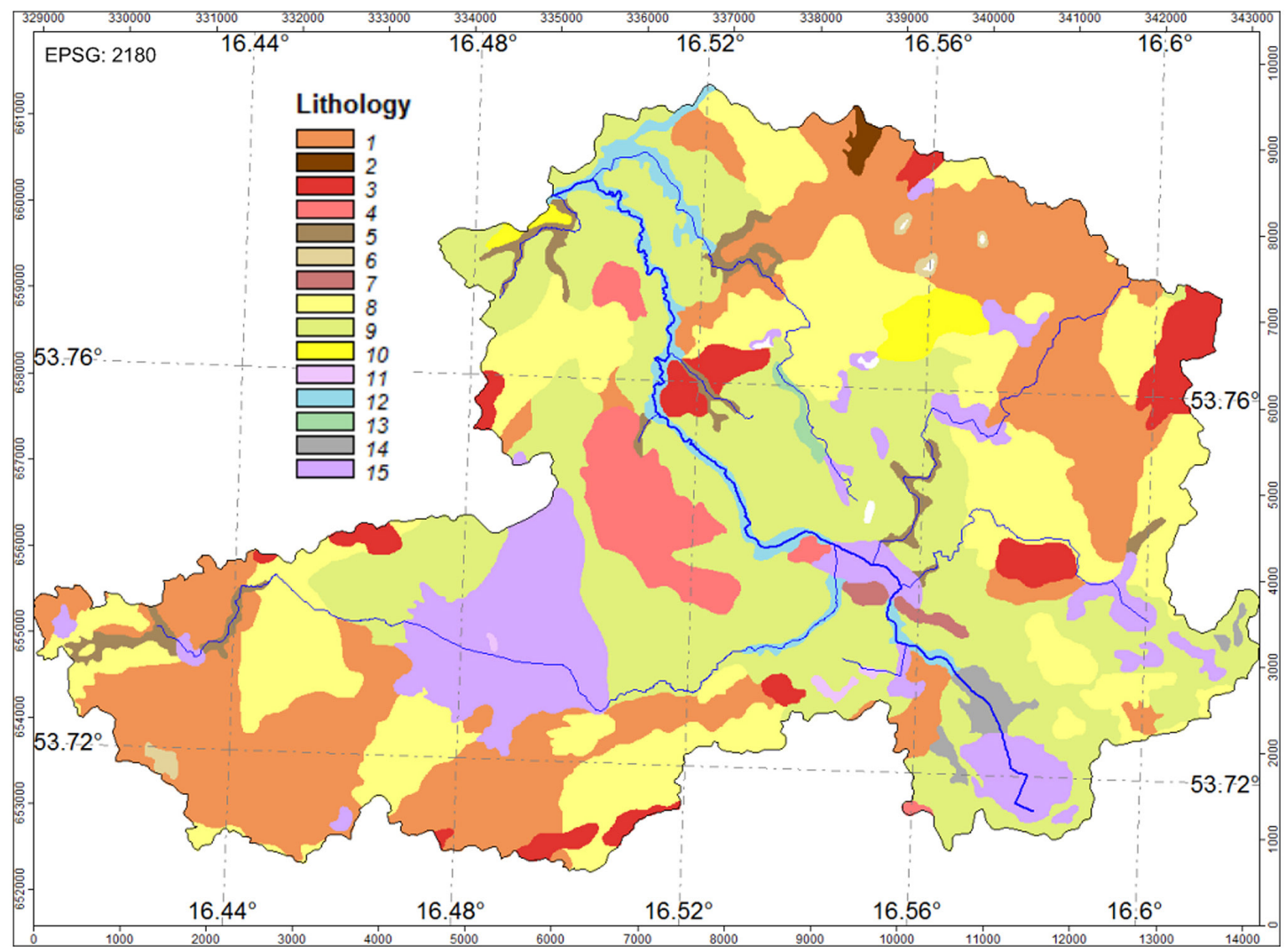

Fig. 7. Lithology of the upper Parsęta catchment according to the Detailed Geological Map of Poland (2004) 1 - tills, 2 - tills of push moraines, 3 - gravels and tills of end moraines, 4 - sands, gravels and tills of kames, 5 - deluvial sands and tills, 6 - melt-out silty sands, 7 - glacial sands and gravels, 8 - glacial gravely and silty sands, 9 - glaciofluvial sands with gravels, 10 - aeolian sands , 11 - humic sands , 12 - fluvial sands of flood plain terraces, 13 - gyttjas, 14 - peaty muds, 15 - peats

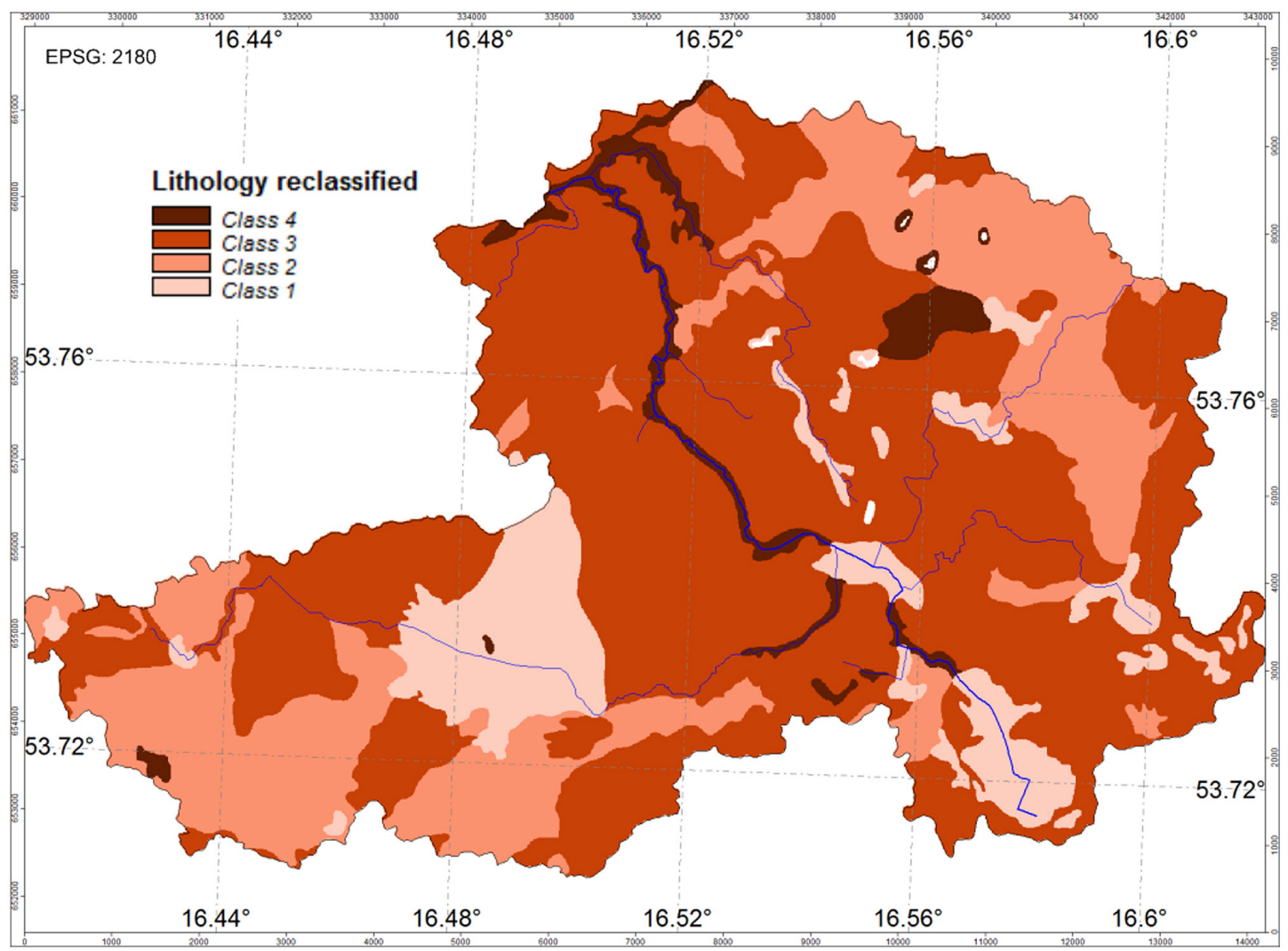

Fig. 8. Reclassified lithology in the upper Parsęta catchment 
The map obtained after the reclassification indicates that areas located in river valleys and in the fields of aeolian sands are characterized by the greatest erosive susceptibility (Fig. 8). Rusty and alluvial soils predominate there. Large, compact surfaces are occupied by the second class area, where rustic soils, podzolic soils, and even luvisols prevail.

\section{Land use and land cover}

The structure of land use and land cover of the upper Parsęta catchment is characterized by considerable diversity (Fig. 9). The mosaic of lands refers to relief, lithology, soils and water conditions. The largest catchment area is occupied by forests (41\%), arable land $(31 \%)$ and grassland (12\%). For this reason, the upper Parsęta catchment can be classified as an agro-forest type. A relatively large area is occupied by peat bogs (2\%) and post-mining excavations (1\%). A small area is occupied by built-up areas ( $2 \%$ of the catchment area) and communication areas (1\%).

Due to the rate of susceptibility to soil erosion, the starting point for the classification of land use and land cover was the division of Wawer and Nowocien (2006), the so-called 6-degree reduction indicator. According to this proposal, soil erosion is mostly limited by such areas as forests, swamps, built-up residential and industrial areas, communication areas. Whereas areas under agricultural lands, mine dumping grounds or burnt vegetation are the most conducive to erosion. The division has been modified. Based on some studies and field research (Klimczak 1993, Robichaud et al. 2010), it can be concluded that erosive processes are also observed in forests, as exemplified by rills and gullies. Moreover, it has been found that erosion is poor in meadow areas. In earlier studies on the upper Parsęta catchment, areas occupied by agriculture with a high degree of natural vegetation were classified as meadow areas (Kostrzewski et al. 1994). In the classification by Wawer and
Nowocień (2006), these grounds are considered to be highly endangered by soil erosion to a degree more similar to arable land than to meadows and pastures. In the correction to the division, an intermediate option was used for these areas. Areas exploited by the opencast method were classified in the same class as arable lands, because the uncovered soil and the lack of vegetation qualifies these areas with high risk of degradation. After the correction for individual land use and types of soil coverage, 4 classes of erosive susceptibility were identified (Table 4).

After the reclassification of the land use and land cover map, an image of spatial distribution for 4 classes of erosion susceptibility was obtained (Fig. 10).

\section{Potential soil erosion in the upper Parsęta catchment}

The final map of the potential soil erosion in the upper Parsęta catchment was obtained on the basis of thematic maps of erosion classes resulting from slopes, LS factor, lithology and land use and land cover types. After overlapping, thematic maps with 4-degree classifications formed a composite map with classes ranging from 4 up to 15 (Fig. 11). Due to the number of classes, the resulting image of potential erosion is opaque. First of all, the areas with the lowest erosion risk (class 1) are visible, located mainly in the bottoms of kettle hole areas.

A numerical map of potential soil erosion in the upper Parsęta catchment was reclassified into a 4-degree division, referring to a 4-degree division of thematic maps (Fig. 12). This way, the least susceptible to water erosion is class 1 that includes sections $4-6$ of the initial result map, class 2 includes sections 7-9, class 3 includes sections $10-12$ and the most susceptible class 4 includes sections 13-15.

Table 4. Classes of susceptibility to erosion by land-use and land-cover (Corine Land Cover) in the upper Parsęta catchment according to the modified Wawer and Nowocień classification (2006)

\begin{tabular}{clc}
\hline $\begin{array}{l}\text { CLC } \\
\text { code }\end{array}$ & Label Level3 & Class of susceptibility to \\
erosion
\end{tabular}




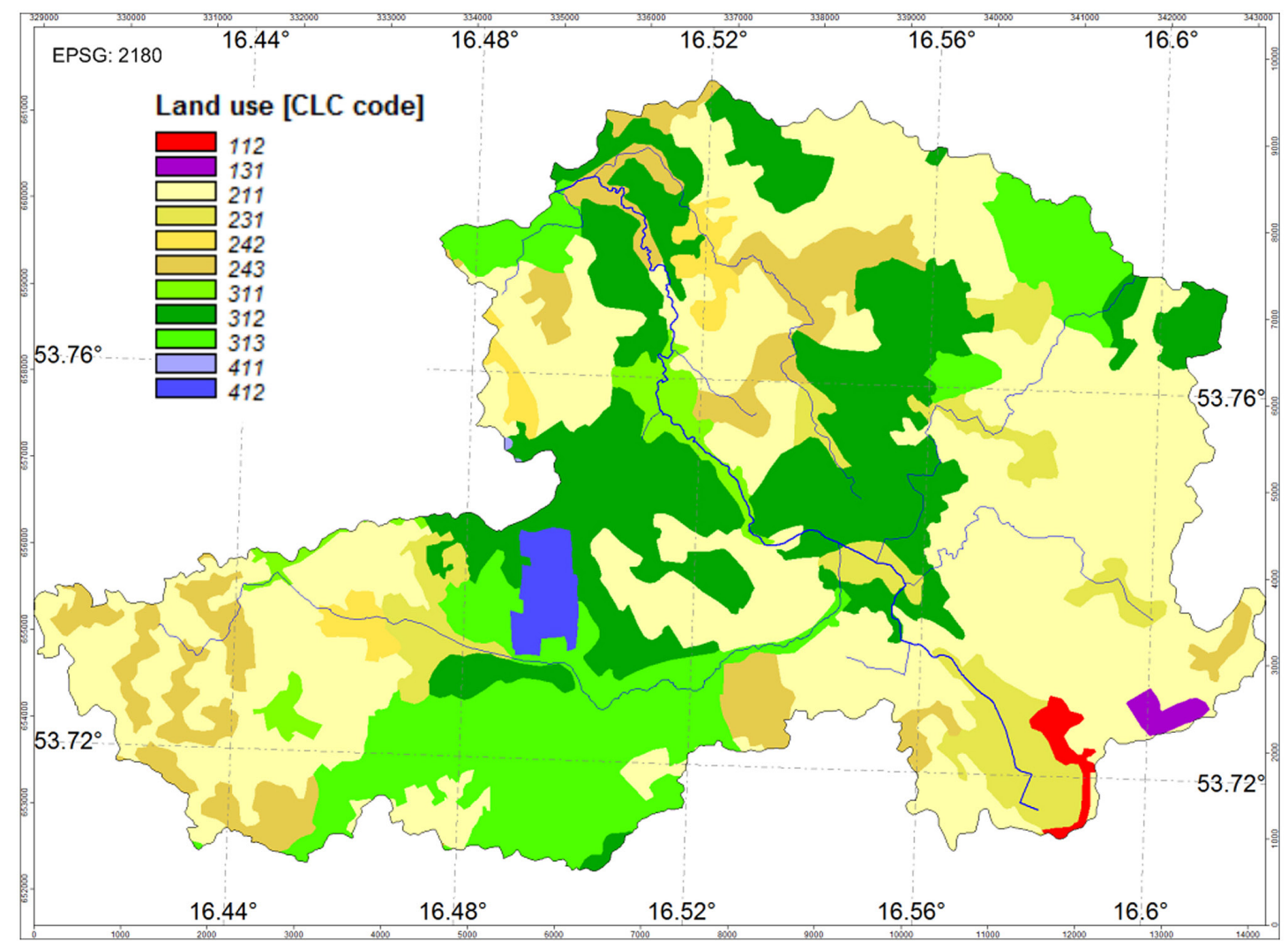

Fig. 9. Land use and land cover in the upper Parsęta catchment

121 - discontinuous urban fabric, 131 - mineral extraction sites, 211 - non-irrigation arable land, 231 - pastures, 242 - complex cultivation patterns, 243 - land principally occupied by agriculture, with significant areas of natural vegetation, 311 - broad-leaved forest, 312 - coniferous forest, 313 - mixed forest, 411 - inland marshes, 412 - peatbogs

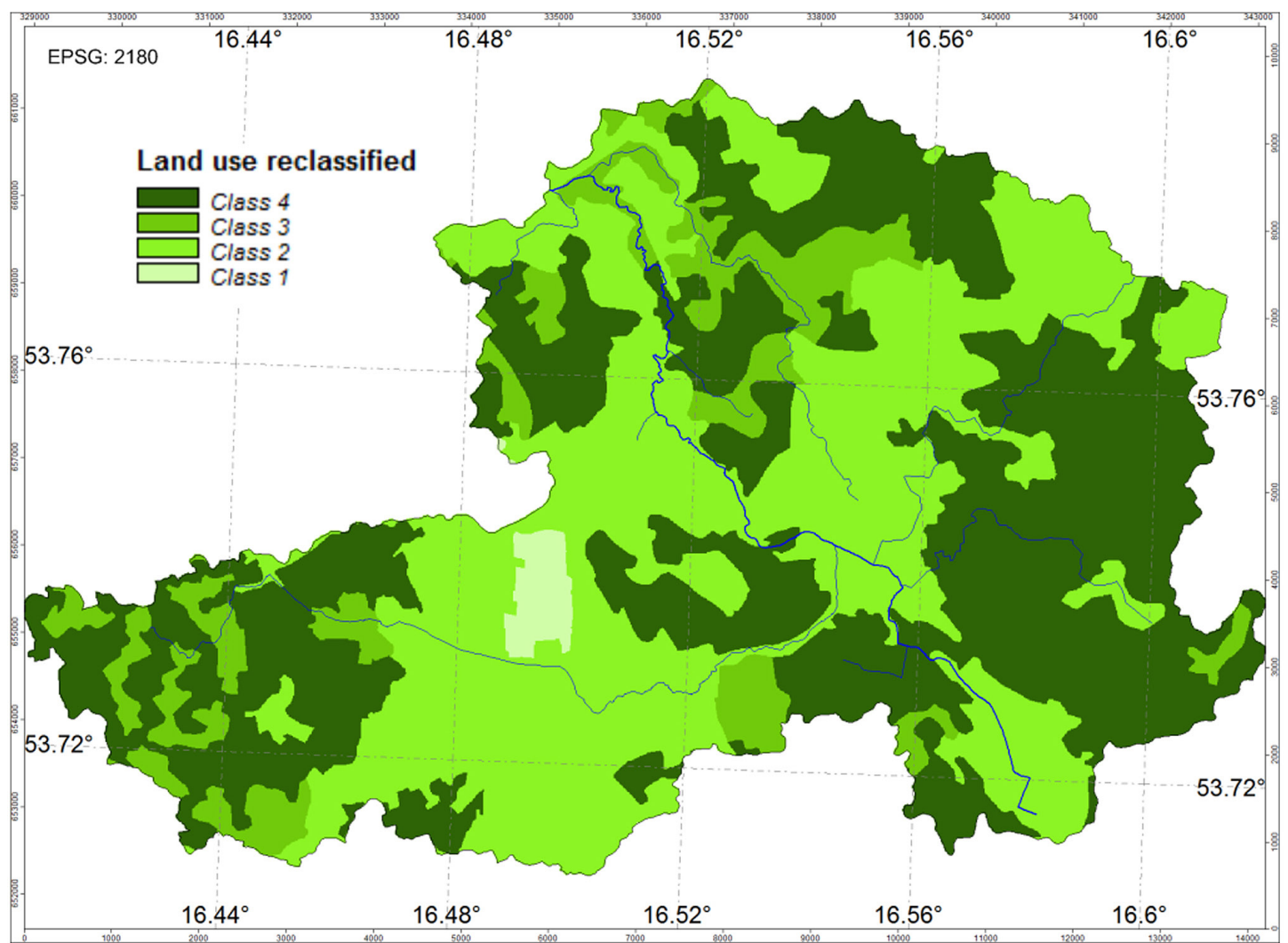

Fig. 10. Reclassified land use and land cover in the upper Parsęta catchment 


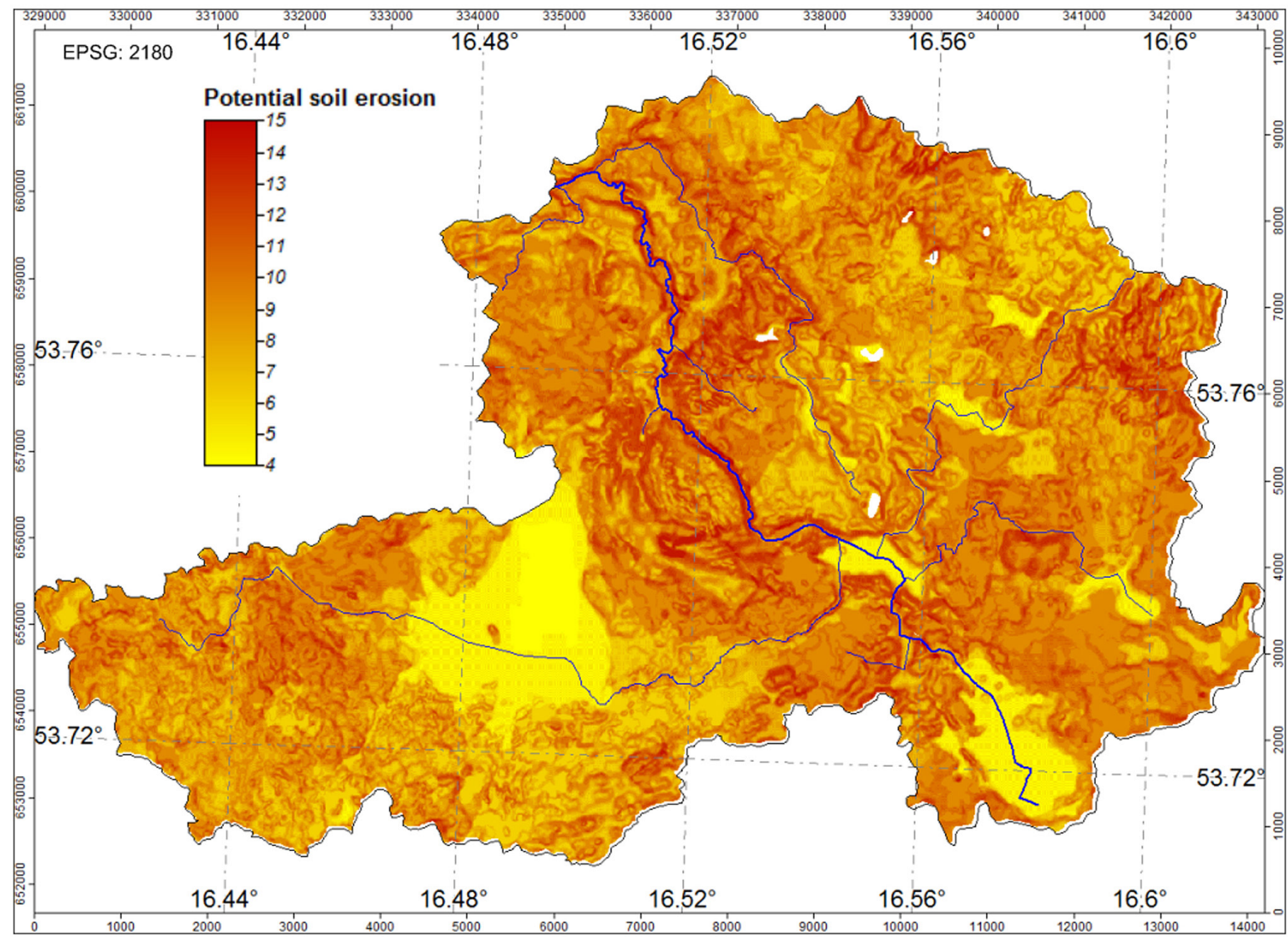

Fig. 11. Potential soil erosion in the upper Parsęta catchment

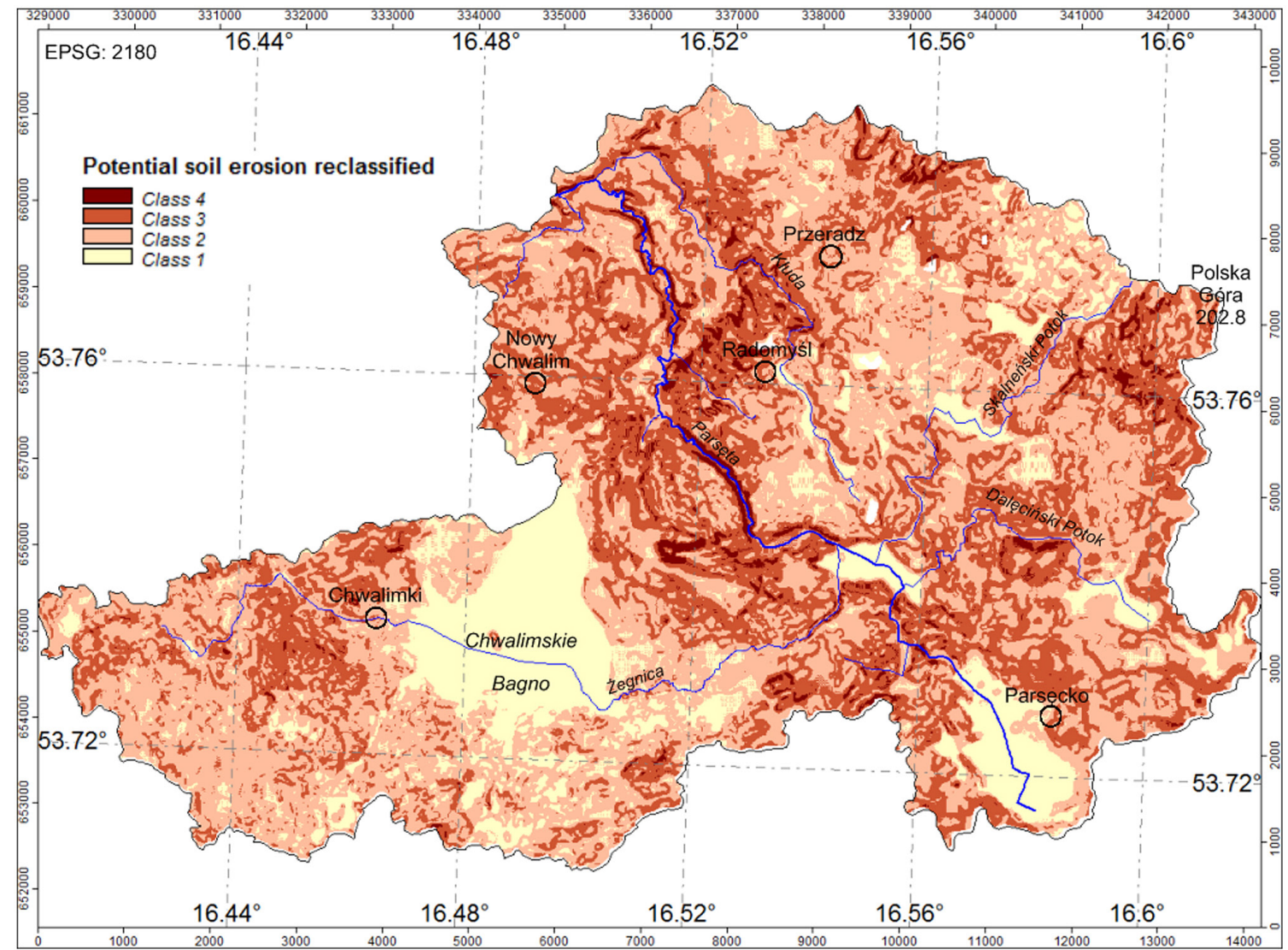

Fig. 12. Reclassified potential soil erosion in the upper Parsęta catchment 
Table 5. Classes of susceptibility to erosion in the upper Parsęta catchment

\begin{tabular}{lcccc}
\hline Class of susceptibility to erosion & 1 & 2 & 3 & 4 \\
\hline Area [\%] & 11.0 & 60.5 & 27.0 & 1.5 \\
\hline
\end{tabular}

The final map of potential soil erosion in the upper Parsęta catchment (Fig. 12) indicates that areas that are most vulnerable to soil erosion (class 1) are bottoms of depressions, including Chwalimskie Bagno, spring area of Parsęta River, spring area of Skalneński Potok and other, much smaller flat areas scattered all over the catchment (Table 5). Areas that are more susceptible to erosion (class 2) occupy as much as $60.5 \%$ of the catchment area and they are grouped on flat or undulated moraine uplands and outwash plains, often covered with forests. Areas with increased erosiveness (class 3) occupy steeper slopes of kame and moraine hills. Greater concentrations of such areas occur around the Polska Góra, on kame hills in the central part of the catchment and area between the kame-kettle zone and the levels of ground moraine to the north and west of Radomyśl. Among areas with the highest susceptibility to soil erosion (class 4), the most visible ones are the edges of the Parsęta Valley in its crucial sections, kame areas between Parsęta and Chwalimskie Bagno, the fragment between the Kłuda Valley and the Parsęta Valley in the central part of the upper Parsęta catchment and areas of moraine uplands at their northern and north-eastern edges.

\section{Discussion and conclusions}

The synthetic map of potential soil erosion indicates that areas particularly susceptible to soil erosion are rare in the upper Parsęta catchment. The 4th class of erosiveness is represented by the edges of the Parsęta Valley and the Kłuda Valley, fragments of the morphological step north and west of Radomyśl, the kame hill between Parsęta and Chwalimskie Bagno and the moraine uplands around the Polska Góra. The main reason for this is morphology, i.e. slope gradient and length of slopes (LS factor). The type of surface formations and the method of covering and using the terrain eliminate the erosive influence of the relief to a large extent. An example is the north-eastern part of the upper Parsęta catchment. This area is within the range of highlands with great local denivelations. However, the presence of till formations and afforestation limits the erosive factors associated with these conditions. In turn, the adjacent part of the catchment, on which there is a slightly loamy sands substrate with a high rate of susceptibility to soil erosion (Szpikowski et al. 2008), combined with a significant degree of inclina- tion of slopes, make the erosive potential of this area high. The kame hill between Parsęta and Chwalimskie Bagno is characterized by slopes with a large degree of inclination $\left(10-20^{\circ}\right)$. This area consists of a substrate made of sands, gravels and loamy sands with an average resistance to soil erosion. However, the erosive potential of the relief is limited by the coniferous forest covering the northern part of the kame. The foot of the south-east part of the kame hills covers arable land, which makes this area very susceptible to denudation.

The areas in the southern part of the Żegnica catchment are less susceptible to soil erosion. There is a diversified relief with medium slope inclinations. This area is occupied mainly by arable land and grassland with a great amount of natural vegetation. In some places there is deciduous forest. The soils are characterized by diversity, with alternating clay formations and various types of sandy-clayey sediments with an admixture of gravels.

The south-eastern part of the upper Parsęta catchment, excluding the Parsęta headwater area, is characterized by a large erosive potential with predominance of second and third class of susceptibility to erosion. The substrate of this area is characterized by the mosaicism of lithological formations. It is caused by diversified landforms with big variations of relative altitude, with moraine uplands, kames, kettle holes and outwash plains. There are peats and peaty silts, clays poorly susceptible to water erosion, moderately susceptible sands, gravels and tills, and very susceptible sands of a variable genesis. However, formations of 3rd and 4th degree of susceptibility to soil erosion prevail. These areas cover the largest areas of arable land in the upper Parsęta catchment. These factors make the erosive potential quite high on slopes with a higher inclination.

The areas with the lowest erosive potential in the upper Parsęta catchment are kettles and ice-dammed lakes. The largest area is occupied by Chwalimskie Bagno in the Żegnica catchment and the Parsęta headwater area. What is more, areas that are least susceptible to soil erosion occur north of the headwater area, in the upper course of Kłuda, east of it in the Skalneński Potok catchment, and also on the south-eastern end of the upper Parsęta catchment in the Dalęciński Potok catchment. They are usually flat moraine uplands or outwash plain fragments.

Small areas with a high rate of susceptibility to soil erosion confirm the thesis that the diversity of the young-glacial relief limits the extent of soil damage. Short slopes, usually not longer than 100 meters, usually cause sheet wash or interrill erosion. The complex spatial arrangement of elevations and depressions reduces the erosive potential of these areas at variable slope inclinations and the stability of erosion bases. Increased soil erosion processes oc- 
cur only locally, within short fragments of catenaries (Smolska 2002, Szpikowski et al. 2008). The numerical map of potential soil erosion in the upper Parsęta catchment confirms these conditions. The structure of land cover and land use play an important role. Stationary studies on soil erosion by water have been carried out on test surfaces with various land use in the upper Parsęta catchment since 1994 (Szpikowski 2012, Majewski 2018). Field experiments using a rain simulator were also made (Majewski 2014). The field research had confirmed the relations of the size of erosion with different agriculture use, for potato crop, soil loss equalled $24 \mathrm{tha}^{-1} \mathrm{y}^{-1}$, for cereals $1-2 \mathrm{tha}^{-1} \mathrm{y}^{-1}$ and for bare fallow $-7,5 \mathrm{t} \mathrm{ha}^{-1} \mathrm{y}^{-1}$. Therefore, there is a large variation in the size of erosion within arable lands resulting from the type of crops and the current state of the agricultural surface (fields in a stage of cultivation without a protective plant cover). Such regularities were confirmed by field research for various regions in Poland (Gil 1999, Rejman 2006, Smolska 2010, Święchowicz 2012). However, the same treatment in the process of modelling the size of erosion (creating maps of potential erosion) of arable lands without dividing them into a type of land is a generalization. Areas with morphological conditions that favour soil erosion are largely covered by forests or meadows.

The accuracy of the map showing the rate of susceptibility to soil erosion, without detailed field tests, depends on the selection of cartographic materials, their scale and classification method. The thematic maps synthesis method and their final classification is of great importance. The use of GIS techniques to present the conditions of potential soil erosion in the upper Parsęta catchment confirms the current research on transformation of the contemporary young glacial relief (Szpikowski et al. 2008).

The methodology for selecting source materials and their classification used in these studies can be modified and more detailed. More detailed morphological data can be obtained DEM from Lidar scanning. The higher resolution of the relief model will allow including such topographic attributes as, for example, vertical and horizontal curvature. The way to make the potential soil erosion map more detailed is a more accurate map of land cover and land use that is based on large-scale satellite data. It would also be important to refer to soil erosiveness, and not to lithology only. An obstacle in this respect is the lack of sufficiently accurate and up-to-date soil maps for the upper Parsęta catchment. When designing a soil erosion map for larger areas than the upper Parsęta catchment, it is necessary to take into account the spatial variability of rainfall erosivity.

The analysis of the relief and the conducted field mapping have shown that in the areas of the 4th class of erosiveness there are forms of older rills and gullies not marked in the relief. This confirms the correctness of the image of spatial variability of potential soil erosion in the upper Parsęta catchment obtained on the map.

\section{Acknowledgments}

We are grateful for valuable comments offered by anonymous reviewers.

\section{Authors' contributions}

Józef Szpikowski - 40\%, Mikołaj Majewski - 40\%, Wojciech Madaj$20 \%$.

\section{References}

Bosco C., Rusco E., Montanarella L., Panagos P., 2009. Soil erosion in the Alpine area: risk assessment and climate change. Studi Trentini di Scienze Naturali 85: 117-123.

Costa Cabral M. C., Burges S. J., 1994. Digital Elevation Model Networks (DEMON): A model of flow over hillslopes for computation of contributing and dispersal areas. Water Resources Research 30(6): 1681-1692.

Dobrzański B., Malicki A., Ziemnicki S., 1953. Erozja gleb w Polsce. Państwowe Wydawnictwo Rolnicze i Leśne, Poznań.

Drzewiecki W., Wężyk P., Pierzchalski M., Szafrańska B., 2014. Quantitative and qualitative assessment of soil erosion risk in Małopolska (Poland), supported by an object-based analysis of high-resolution satellite images. Pure and Applied Geophysics $171(6)$ : 867-895.

Erhard M., Böken H., Glante F., 2003. The assessment of the actual soil erosion risk in Germany, based on CORINE Land-Cover and statistical data from the main representative survey of land use. In: R.Francaviglia (ed.), Agricultural Impacts on Soil Erosion and Soil Biodiversity: Developing Indicators for Policy Analysis. Proceedings from an OECD Expert Meeting, Rome: 253-262.

Farhan Y., Zregat D., Farhan I., 2013. Spatial estimation of soil erosion risk using RUSLE approach, RS, and GIS techniques: a case of study of Kufranja Watershed, Northern Jordan. Journal of Water Resource and Protection 5: 1247-1261.

Favis-Mortlock D.T., Quinton J.N., Dickinson W.T., 1996. The GCTE validation of soil erosion models for global change studies. Journal of Soil and Water Conservation 51: 397-403.

Gerlach T, 1966. Współczesny rozwój stoków w dorzeczu górnego Grajcarka (Beskid Wysoki - Karpaty Zachodnie). Prace Geograficzne IG PAN 52.

Gil E., 1976. Spłukiwanie gleby na stokach fliszowych w rejonie Szymbarku. Dokumentacja Geograficzna 2.

Gil E., 1999. Obieg wody i spłukiwanie na fliszowych stokach użytkowanych rolniczo w latach 1980-1990. Zeszyty IGiPZ PAN, 60: 1-78.

Jenks G.F., 1967. The Data Model Concept in Statistical Mapping, International Yearbook of Cartography 7: 186-190.

Józefaciuk A., Józefaciuk Cz., 1992. Struktura zagrożenia erozją wodną fizjograficznych krain Polski. Pamiętnik Puławski 101: 23-49.

Józefaciuk A., Józefaciuk Cz., 1994. Próba erozyjnej rejonizacji obszarów Polski dla celów melioracji przeciwerozyjnych. Roczniki Akademii Rolniczej w Poznaniu 266, Melioracje i Inżynieria Środowiska 14: 273-280.

Józefaciuk A., Józefaciuk Cz., 1996. Mechanizm i wskazówki metodyczne badania procesów erozji. Biblioteka Monitoringu Środowiska, Warszawa.

Józefaciuk A., Józefaciuk Cz., 1999. Ochrona gruntów przed erozją. Wydawnictwo IUNG. Puławy. 
Józefaciuk A., Józefaciuk Cz., Nowocień E., 1999. Erozja wodna w zlewniach rzek Przymorza Bałtyku. In: A.Kostrzewski (ed.), Funkcjonowanie geoekosystemów zlewni rzecznych 2: 81-86.

Józefaciuk Cz., Józefaciuk A., Barbaś S., Budzyńska K., 1985. Metoda opracowania mapy potencjalnej erozji wodnej gleb w Polsce. Roczniki Gleboznawcze 36(1): 177-183.

Józefaciuk Cz., Józefaciuk A., Nowocień E., Wawer R., 2001a. Erozja wąwozowa w województwie zachodniopomorskim. Folia Universitatis Agriculturae Stetinensis 217, Agricultura 87: 73-76.

Józefaciuk Cz., Józefaciuk A., Nowocień E., Wawer R., 2001b. Struktura zagrożenia gleb erozją wodną powierzchniową w województwie zachodniopomorskim. Folia Universitatis Agriculturae Stetinensis 217, Agricultura 87: 65-68.

Karczewski A., 1989. Morfogeneza strefy marginalnej fazy pomorskiej na obszarze loby Parsęty w vistulianie (Pomorze Środkowe). Wydawnictwo Naukowe UAM, Poznań.

Kirkby M.J., Jones R.J.A., Irvine B., Gobin A, Govers G., Cerdan O., Van Rompaey A.J.J., Le Bissonnais Y., Daroussin J., King D., Montanarella L., Grimm M., Vieillefont V., Puidgefabregas J., Boer M., Kosmas C., Yassoglou N., Tsara M., Mantel S., Van Lynden G.J., Huting J., 2004. Pan-European Soil Erosion Risk Assessment: The PESERA Map, Version 1 October 2003. Explanation of Special Publication Ispra 2004 No.73 (S.P.I.04.73). European Soil Bureau Research Report No.16, EUR 21176, Office for Official Publications of the European Communities, Luxembourg.

Klimczak R., 1993. Spłukiwanie na obszarach o zróżnicowanym użytkowaniu - przebieg i rola we współczesnym środowisku morfogenetycznym (zlewnia Młyńskiego Potoku, Pomorze Zachodnie). Zeszyty Naukowe PAN 6: 61-77.

Koćmit A., 1998. Erozja wodna w obszarach młodoglacjalnych Pomorza i możliwości jej ograniczenia. Biblioteca Fragmenta Agronomica 4B (98): 83-96.

Koreleski K., 1992. Próby oceny natężenia erozji wodnej. Zeszyty Naukowe Akademii Rolniczej im. H. Kołłątaja w Krakowie, Sesja Naukowa 35: 91-100.

Kostrzewski A., 2001. Stan badań erozji gleb na Pomorzu Zachodnim. Folia Universitatis Agriculturae Stetinensis 217, Agricultura 87: 117-124.

Kostrzewski A., Mazurek M., Zwoliński Z., 1994. Dynamika transportu fluwialnego górnej Parsęty jako odbicie funkcjonowania systemu zlewni. Bogucki Wydawnictwo Naukowe, Poznań.

Kostrzewski A., Zwoliński Z., Andrzejewski L., Florek W., Mazurek M., Niewiarowski W., Podgórski Z., Rachlewicz G., Smolska E., Stach A., Szmańda J., Szpikowski J., 2008. Współczesny morfosystem strefy młodoglacjalnej. Landform Analysis 7: 7-11.

Kosturkiewicz A., Szafrański Cz., Fiedler M., 1994. Agromelioracje jako czynnik ograniczający erozję wodną gleb terenów bogato rzeźbionych. Roczniki Akademii Rolniczej w Poznaniu 266, Melioracje i Inżynieria Środowiska 14: 281-293.

Laflen J.M., Lane L.J., Foster G.R., 1991. WEPP - a next generation of erosion prediction technology. Journal of Soil and Water Conservation 46: 34-38.

Le Bissonnais Y., Montier C., Jamagne M., Daroussin J., King D., 2002. Mapping erosion risk for cultivated soil in France. Catena 46: 207-220.

Lu D., Li G., Valladares G.S., Batistella M., 2004. Mapping soil erosion risk in Rondônia, Brazilian Amazonia: using RUSLE, remote sensing and GIS. Land Degradation \& Development 15: 499-512.

Majewski M., 2014. Wykorzystanie eksperymentu terenowego w badaniach erozji wodnej gleb w zlewni Chwalimskiego Potoku (Pojezierze Drawskie, górna Parsęta). Prace Geograficzne UJ 138: 57-66.

Majewski M., 2018. Erozja wodna gleb w zlewni Chwalimskiego Potoku (Pojezierze Drawskie) w latach 2012-2017. In: W.Bochenek, M.Kijowska-Strugała (eds), Zintegrowany Monitoring Środowiska Przyrodniczego - Ocena funkcjonowania i kierunków zmian środowiska przyrodniczego Polski na podstawie wieloletnich badań stacjonarnych, Biblioteka Monitoringu Środowiska, Szymbark: 191-197.

Martín-Fernándes L., Martínez-Núňez M., 2011. An empirical approach to estimate soil erosion risk in Spain. Science of the Total Environment 409: 3114-3123.

Milevski I., 2008. Estimation of soil erosion risk in the upper part of Bregalnica watershed - Republic of Macedonia, based on digital elevation model and satellite imagery. Proceedings from the 5th International conference on geographic information systems, Fatih University, Istanbul: 351-358.

Morgan R.P.C., Quinton J.N., Smith R.E., Govers G., Poesen J., Auerswald K., Chisci G., Torri D., Styczen M.E., 1998. The European Soil Erosion Model (EUROSEM): a dynamic approach for predicting sediment transport from fields and small catchments. Earth Surface Processes and Landforms 23(6): 527-544.

Mularz S., 1995. Zastosowanie GIS do oceny zagrożenia erozyjnego pokrywy glebowej. Archiwum Fotogrametrii, Kartografii i Teledetekcji 3: 33-42.

Mularz S., Drzewiecki W., 2007. Ocena zagrożenia gleb erozją wodną w rejonie Zbiornika Dobczyckiego w oparciu o wyniki numerycznego modelowania. Archiwum Fotogrametrii, Kartografii i Teledetekcji 17b: 535-548.

Panagos P., Ballabio C., Borrelli P., Meusburger K., Klik A., Rousseva S., Tadic M.P., Michaelides S., Hrabalíková M., Olsen P., Aalto J., Lakatos M., Rymszewicz A., Dumitrescu A., Beguería S., Alewell C., 2015. Rainfall erosivity in Europe. Science of the Total Environment 511: 801-814.

Państwowy Instytut Geologiczny, 2004. Szczegółowa Mapa Geologiczna Polski. Arkusz 159 - Barwice, arkusz 160 - Szczecinek, Warszawa.

Perović V., Životić L., Kadović R., Dordević A., Jaramaz D., Mrvic V., Todorović M., 2013. Spatial modelling of soil erosion potential in a mountainous watershed of South-eastern Serbia. Environmental Earth Sciences 68(1): 115-128.

Prasuhn V., Liniger H., Gisler S., Herweg K., Candinas A., Clément J. P., 2013. A high-resolution soil erosion risk map of Switzerland as strategic policy support system. Land Use Policy 32: 281-291.

Rejman J., 2006. Wpłw erozji wodnej i uprawowej na przekształcanie stoków lessowych. Acta Agrophysica, 136(3).

Renard K.G., Foster G.R., Weesies G.A, McCool D.K. Yder D.C., 1997. Predicting Soil Erosion by Water: A Guide to Conservation Planning with the Revised Universal Soil Loss Equation (RUSLE) (Agricultural Handbook 703). US Department of Agriculture, Washington DC.

Reniger A., 1950. Próba oceny nasilenia i zasięgów potencjalnej erozji gleb w Polsce. Roczniki Nauk Rolniczych 54.

Robichaud P.R., Wagenbrenner J.W., Brown R.E., 2010. Rill erosion in natural and disturbed forest. Water Resources Research, 46: 1-14.

Smolska E., 2002. The intensity of soil erosion in agricultural areas in North-Eastern Poland. Landform Analysis 3: 25-33.

Smolska E., 2010. Spływ wody i erozja gleby na piaszczystym stoku w obszarze młodoglacjalym (Pojezierze Suwalskie, Polska NE) - pomiary poletkowe. Prace i Studia Geograficzne, 45: 197-214.

Šúri M., Cebecauer T., Hofierka J., Fulajtár E., 2002. Soil Erosion Assessment of Slovakia at a Regional Scale Using GIS. Ecology (Bratislava) 21(4): 404-422.

Szpikowski J., 2003. Contemporary processes of soil erosion and the transformation of the morphology of slopes in agricultural use in the postglacial catchment of the Chwalimski Potok (Upper Parsęta, Drawskie Lakeland). Quaestiones Geographicae 22: 79-90.

Szpikowski J., 2012. Uwarunkowania i wielkość erozji wodnej gleb i denudacji agrotechnicznej na Pojezierzu Drawskim (Pomorze Zachodnie). In: A.Kostrzewski, J.Szpikowski (eds), Zintegrowany Monitoring Środowiska Przyrodniczego: Funkcjonowanie geoekosystemów w różnych strefach krajobrazowych Polski. Bibliotek Monitoringu Środowiska, Storkowo: 83-95.

Szpikowski J., Kostrzewski A., Mazurek M., Smolska E., Stach A., 2008. Współczesne procesy kształtujące rzeźbę stoków. In: 
L.Starkel, A.Kostrzewski, A.Kotarba, K.Krzemień (eds), Współczesne przemiany rzeźby Polski. Instytut Geografii i Gospodaki Przesrzennej UJ, Kraków: 283-293.

Święchowicz J., 2012. Wartości progowe opadów deszczu inicjujących procesy erozyjne $\mathrm{w}$ zlewniach użytkowanych rolniczo. IGiGP Uniwersytetu Jagiellońskiego, Kraków.

Tricart J., Kiewiet de Jonge C., 1992. Ecogeography and rural management - a contribution to the International Geosphere-Biosphere Programme. Harlow, U.K.

Urbański J., 2008. GIS w badaniach przyrodniczych. Wyd. Uniwersytetu Gdańskiego.

Vold T., Sondheim M.W., Nagpal N.K., 1985. Computer assisted mapping of soil erosion potential. Canadian Journal of Soil Science 65: 411-418.

Vrieling A., Sterk G., Beaulieu N., 2002. Erosion risk mapping: A methodological case study in the Colombian Eastern Plains. Journal of Soil and Water Conservation 57, 3: 158-163.

Wawer R., Nowocień E., 2006. Mapa erozji wodnej aktualnej w oparciu o Corine Land Cover 2000. Pamiętnik Puławski 142: 537-546.
Wawer R., Nowocień E., 2007. Digital map of water erosion risk in Poland: a qualitative, vector-based approach. Polish Journal of Environmental Studies 16 (5): 763-772.

Wawer R., Nowocień E., Podolski B., Capała M., 2008. Ocena zagrożenia erozją wodną zlewni rzeki Bystrej $z$ wykorzystaniem modelowania przestrzennego. Przegląd Naukowy. Inżynieria i Kształtowanie Środowiska 17/3(41): 20-28.

Wężyk P., Drzewiecki W., Wójtowicz-Nowakowska A., Pierzchalski M., Mlost J., Szafrańska B., 2012. Mapa zagrożenia erozyjnego gruntów rolnych w Małopolsce na podstawie klasyfikacji OBIA obrazów teledetekcyjnych oraz analiz przestrzennych GIS. Archiwum Fotogrametrii, Kartografii i Teledetekcji 24: 403-420.

Wischmeier W.H., Smith D.D., 1978. Predicting rainfall erosion losses: A guide to conservation planning. Agricultural Handbook 537, U.S. Department of Agriculture, Washington D.C.

Ziemnicki S., 1978. Mechanizm działania erozji wodnej. [In:] S. Ziemnicki (ed.), Erozja Wodna. Pań. Wyd. Rolnicze i Leśne, Warszawa: 20-32. 